\title{
Compilation and analysis of international from-whom-to-whom financial stock table for Japan, Korea, the United States, and China
}

\author{
Satoru Hagino ${ }^{1}$ and Jiyoung Kim ${ }^{2^{*}}$ (D)
}

\author{
*Correspondence: \\ jiyoung@okayama-u.ac.jp \\ ${ }^{2}$ Graduate School \\ of Humanities and Social \\ Sciences, Okayama University, \\ 3-1-1 Tsushima-naka, Kita-ku, \\ Okayama 700-8530, Japan \\ Full list of author information \\ is available at the end of the \\ article
}

\begin{abstract}
This paper discusses the development of international flow of funds accounts; it compiles and analyzes such accounts with a focus on the global financial crisis. For this purpose, we compile from-whom-to-whom financial stock tables for Japan, Korea, the United States, and China and combine these tables to generate a four-country international from-whom-to-whom financial stock table. Input-output analyses reveal that nonfinancial corporations in the four countries have the largest liability power-ofdispersion and that the Japanese government's liability power-of-dispersion is large. In contrast, the financial institution sector in Japan has the largest asset power-ofdispersion. In the future, the table could be expanded to include other major AsiaPacific countries and linked to Euro-area from-whom-to-whom financial stock tables to provide a global from-whom-to-whom financial stock table.
\end{abstract}

Keywords: Global financial crisis, Input-output analysis, International flow of funds accounts, International from-whom-to-whom financial stock table, Power-of-dispersion

JEL Classification: R15, F30

\section{Background}

Briefly reviewing the world economy of recent years reveals that a savings glut has caused public debt problems in developed economies. On the other hand, a lack of investment has undermined economic growth in underdeveloped countries. Discrepancies among the financial systems of developed and developing countries hinder the global redistribution of funds. Both financial and real sectors should be considered in analyzing the global economy. Financial transactions and trades are two sides of the same coin. Financial transactions among the entities of multiple countries make up the global financial market, whereas international trade reflects the real economy. As is well known, international input-output tables that measure the real sector have been developed. However, statistics for international financial relations remain undeveloped.

Flow of funds accounts (FFAs) are official statistics describing fund transfers and asset/liability holdings within and outside a country. Global FFAs depict the crossborder transfer of funds at the international level and the countries' consequent claim/

(c) The Author(s), 2021. Open Access This article is licensed under a Creative Commons Attribution 4.0 International License, which permits use, sharing, adaptation, distribution and reproduction in any medium or format, as long as you give appropriate credit to the original author(s) and the source, provide a link to the Creative Commons licence, and indicate if changes were made. The images or other third party material in this article are included in the article's Creative Commons licence, unless indicated otherwise in a credit line to the material. If material is not included in the article's Creative Commons licence and your intended use is not permitted by statutory regulation or exceeds the permitted use, you will need to obtain permission directly from the copyright holder. To view a copy of this licence, visit http:// creativecommons.org/licenses/by/4.0/. 
obligation relations. Although the original idea of global FFAs is seen in pioneering works, such as that of Ishida (1993), worldwide currency and financial crises, especially the 2008 global financial crisis, have shed new light on the importance of global FFAs. The Financial Crisis and Information Gaps, Report to the G-20 Finance Ministers and Central Bank Governor, or the so-called G20 Data Gap Report, was published in 2009 by the International Monetary Fund (IMF) Staff and the Financial Stability Board Secretariat to frame a guideline for filling the data gap between existing and necessary statistical assets of the global financial system, and the development of global FFAs was set as its key objective.

The development of global FFAs has been primarily driven by the IMF, which is responsible for monitoring global financial system functions. For example, in line with the global FFA scheme of Errico et al. $(2013,2014)$, the IMF has worked on improving relevant international statistics, such as those of the Coordinated Portfolio Investment Survey (CPIS) and the Coordinated Direct Investment Survey (CDIS). Global FFAs, however, have not yet been produced, mainly due to the absence of national "fromwhom-to-whom" FFAs to be combined as the integral segments of global FFAs. ${ }^{1}$

Against this backdrop, this paper considers the possibility and relevance of compiling global FFAs, particularly extending the compilation to international "from-whom-towhom" financial stock (FFS) tables. Such a compilation would be based on information obtained from a series of dialogs with experts of the IMF as well as the Bank of Japan, the Bank of Korea, the (US) Federal Reserve, and Statistics Canada, each of which is responsible for compiling its respective country's FFAs. In the next section, we first present a method for transforming national FFAs into FFS tables and then show how the consequent FFS tables are integrated with CPIS, CDIS, and other international statistics within the framework of an international FFS table, with a particular focus on the Asia-Pacific Region. We later discuss the potential use of an international FFS table in input-output analysis.

Previous research has analyzed international flows of funds. For example, Tsujimura and Tsujimura $(2008,2009,2010,2011)$ constructed tables for financial transactions among multiple countries. Zhang $(2005,2009,2015)$ and Zhang and Zhao (2019) built global flow of funds models comprising the financial instruments of major countries and estimated several multiple-equation models. Schumacher (2019) analyzed intercountry credit and savings to evaluate the effects of credit defaults.

The authors' previous study, Hagino et al. (2018), converted the FFAs of Japan, Korea, the United States, and Canada into FFS tables and compiled an international FFS table connecting the four countries and representing a preliminary global FFA focused on the Asia-Pacific Region. In doing so, the authors exchanged views with experts from the Bank of Japan, the Bank of Korea, the US Federal Reserve Board, and Statistics Canada, who are compilers of their countries' FFAs, as well as at the IMF, to discuss a method of converting countries' FFAs into FFSs and putting those FFSs, CPISs, CDISs, and other international statistics into a global FFS framework. For a future project, we propose including China, Brazil, and Chile, as well as Indonesia and Colombia, which have been

${ }^{1}$ Some countries are expected to produce these tables in the near future in compliance with IMF's Special Data Dissemination Standards (SDDS) Plus. 
developing their FFAs, to compile a comprehensive Asia-Pacific FFS. We also exchanged views with researchers at the National Accounts Institute of Beijing Normal University Measurement regarding the contemplated future project. With the goal in mind of including China in the Asia-Pacific FFS, it was suggested that the most important obstacle is the absence of stock data for China's FFA, in addition to obstacles derived from the relatively slow pace of China's statistics development in CPIS and CDIS.

Under these circumstances, the authors decided to estimate a stock table of China's FFA and then compile an FFS table as described in the work of Hagino et al. (2018), aiming to include China in the Asia-Pacific FFS. In this respect, it may be efficient to replace Canada, which was included in the preliminary Asia-Pacific FFS of Hagino et al. (2018), with China. Compiling Canada's FFS required many assumptions due to a lack of source data, while China's slow development in CPIS and CDIS implies that mirror data of China's partner countries may be used. Thus, the new Asia-Pacific FFS will consist of Japan, Korea, the United States, and China. This paper attempts to achieve this goal by producing a stock table for China's FFAs as of year-end 2015 and examining the use of various financial data. Hagino et al. (2019) estimated an FFS table for Japan, Korea, the United States, and China.

The remainder of this paper is organized as follows. Section 2 explains the basic concept and framework of the FFA. After converting FFAs into FFSs for Japan, Korea, the United States, and China, a new Asia-Pacific international FFS as of year-end 2015 is demonstrated. Section 3 analyzes power and sensitivity indexes using an input-output analysis method and describes features of asset and liability portfolios. Finally, Sect. 4 presents the conclusion and prospects for future projects.

\section{Methods}

\subsection{Compilation methods for from-whom-to-whom financial stock tables}

An $\mathrm{FFA}^{2}$ represents the financial economy in matrix form with economic sectors, such as financial institutions (FIs), NFCs, general government (GG), households (HHs), and the rest of the world (ROW), in columns; and financial transactions or asset/liability items, such as deposits, loans, debt securities, equity shares, and insurance/pension reserves (IPs), in rows. Even though FFAs include stock tables of financial assets/liabilities and flow tables of financial transactions as their major components, the compilers of the accounts came to adopt common usage of the term "flow of funds" following the seminal work of Copeland (1952). Thus, financial transaction or flow tables and financial asset/liability or stock tables are major components of FFAs. Currently, Japan, Korea, and the United States submit FFA data to the Organization for Economic Co-operation and Development, which publishes these countries' FFA data in a standardized form.

Figure 1 is an outline of the FFA and FFS tables. In this section, we first summarize the compilation methods of FFS tables for Japan, Korea, and the United States using the stock data of FFAs. As stock data for China's FFAs have not been officially released, we explain how to estimate stock data for China and create an FFS table.

\footnotetext{
${ }^{2}$ In the System of National Accounts (SNA), however, financial transaction or flow tables refer to financial accounts, and financial asset/liability or stock tables refer to sectoral balance sheets. It appears that this SNA terminology has been widely used in Europe and was recently adopted by the US Federal Reserve as well. Nevertheless, this paper uses the terminology "flow of funds," as it is a convenient for covering both flow and stock tables.
} 


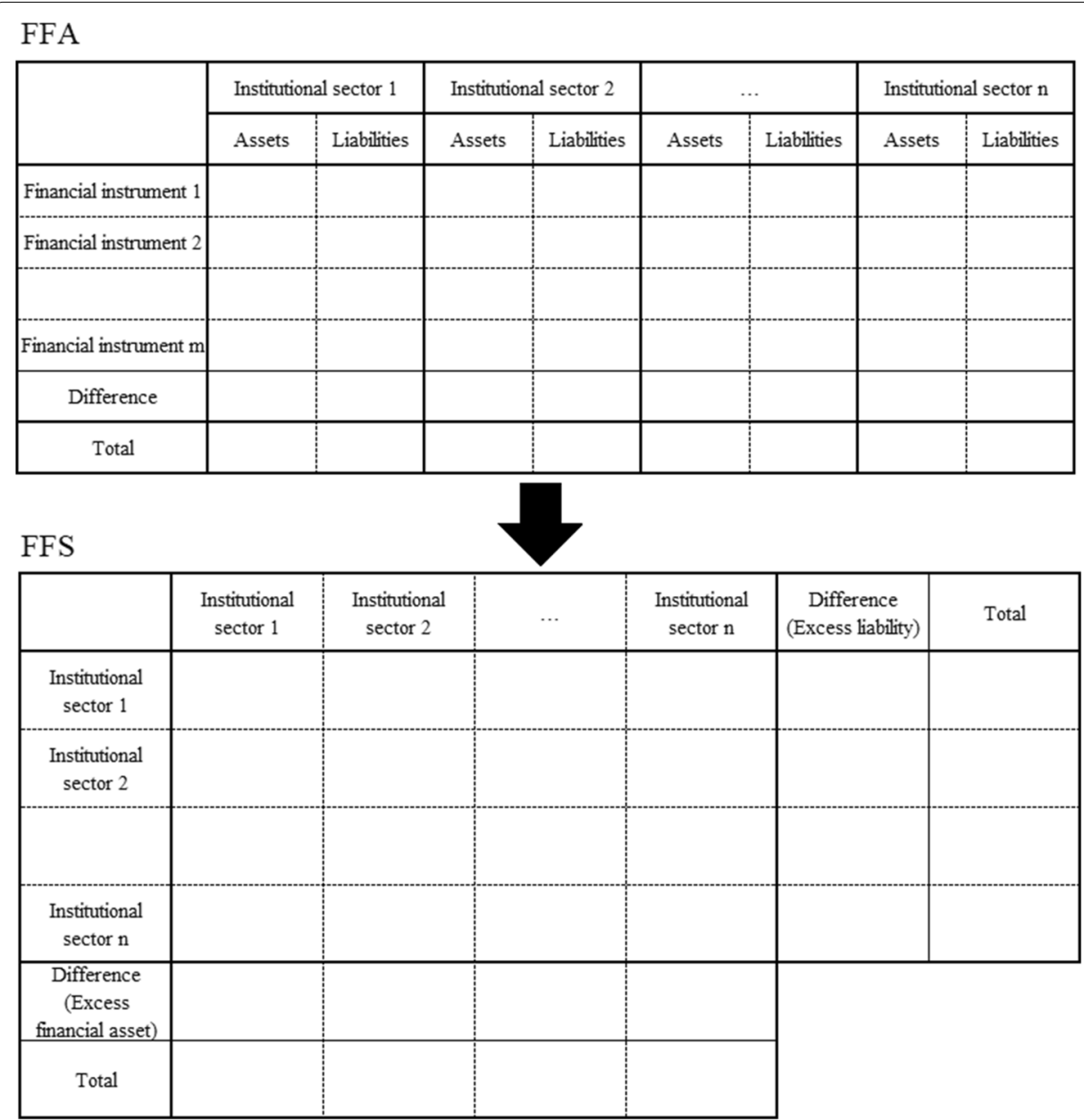

Fig. 1 Conversion of flow of funds accounts into from-whom-to-whom financial stocks

\subsection{Reconstruction of domestic from-whom-to-whom financial stock table}

Table 1 presents an FFS table for Japan converted from Japan's FFAs. The table shows the liabilities of each sector in rows and the assets of each sector in columns. For each column, the holdings of the relevant sector's liabilities can be identified by sector. For example, of the 13,652 billion USD total liabilities of the NFC sector, 6221 billion USD are held by FIs, and 3858 billion USD are held by NFCs. Using the explanation for industrial input-output tables, such data imply how each sector's financial needs are satisfied by its own and other sectors.

The financial asset and liability composition ratios used by Okuma (2013) were adopted to compile an FFS table for Japan. Specifically, based on Okuma's (2013) FFS stock table for year-end 2011, the ratios of financial assets and liabilities can be identified (the ratios of holding amounts of a sector to the total liabilities of a sector). Assuming the relationship between domestic assets and liabilities is stable, such ratios are applied to the data at year-end 2015. In contrast, the international asset/liability relationship is derived from foreign asset/liability holding ratios by sector according to the net international position. 
Table 1 FFS Table for Japan (in units of 1 billion USD)

\begin{tabular}{llllllll}
\hline & FI & NFC & GG & HH & ROW & $\begin{array}{l}\text { Excess } \\
\text { liability }\end{array}$ & Total \\
\hline FI & 8321 & 6221 & 8320 & 3091 & 4857 & 0 & 30,811 \\
NFC & 3277 & 3858 & 218 & 245 & 1619 & 4434 & 13,652 \\
GG & 1613 & 1088 & 966 & 88 & 1451 & 5551 & 10,756 \\
HH & 14,073 & 846 & 240 & 0 & 78 & 0 & 15,292 \\
ROW & 2377 & 1639 & 1011 & 66 & 0 & 2912 & 8005 \\
Excess & 1150 & 0 & 0 & 11,776 & 0 & & \\
Financial asset & & & & & & & \\
Total & 30,811 & 13,652 & 10,756 & 15,292 & 8005 & & \\
\hline
\end{tabular}

Source: created by authors using OECD.Stat data

In this table, the vertical and horizontal totals should match, but in practice, they do not. This discrepancy results from the different sources used and the different net position at year-end 2015 compared with 2011. Although such discrepancies can be eliminated by calculating the convergent matrix, they have been absorbed in $\mathrm{HH}$ assets and liabilities by calculating them as a residual.

Okuma (2013) classified FFA data into four categories. The first category refers to instruments whose issuers or holders can be identified by their financial instruments alone, including currency, deposits, and loans. The second category refers to instruments whose holders can be identified by additional sources. For example, foreign deposits held by the government can be identified from Ministry of Finance data. The third category refers to government bonds of financial investments and loan program bonds with FI or GG issuers. In this case, the total liabilities are split into two types of bonds in each holding sector based on total issuance amounts. The fourth category refers to instruments for which irrelevant issuing/holding sectors can be eliminated by judgment.

Such categorization and corresponding estimation methods are similar to the summary of FFS table compilation methods, as mentioned at the beginning of this section. The peculiarity of the method used by Okuma (2013) is its minimization of proration, which can improve the accuracy of FFS data. At the same time, Okuma (2013) notes the difficulties in compiling FFS tables for Japan, such as pension fund assets being regarded as those of entrusted FIs in a shareholding sector survey. At any rate, it is expected that the Bank of Japan will overcome such difficulties and produce qualified FFS tables for Japan that comply with the IMF's SDDS Plus.

Korea's FFS tables are compiled in Table 2. Lee (2014) estimated FFS tables for Korea using data through the end of 2012. This data identified partner sectors for $60 \%$ of the total financial assets. Broken down by sectors, partner sectors were identified for more than $70 \%$ of the FI, GG, and HH sectors. In contrast, partner sectors were identified for less than $30 \%$ of the NFC and ROW sectors, mainly because these sectors use shares, foreign direct investments, and trade credits more than other sectors. Based on information derived from Lee (2014), all the financial asset/liability composition ratios were estimated. Table 2 is compiled using these ratios and the net international position statistics from the end of 2015.

Table 3 shows the FFS table for the United States. As concerns US data, the IMF compiles a financial corporations survey based on US FFAs. This survey presents US FI 
Table 2 FFS Table for Korea (in units of 1 billion USD)

\begin{tabular}{llllllll}
\hline & FI & NFC & GG & HH & ROW & $\begin{array}{l}\text { Excess } \\
\text { liability }\end{array}$ & Total \\
\hline FI & 1643 & 1445 & 106 & 505 & 320 & 0 & 5614 \\
NFC & 434 & 189 & 8 & 0 & 329 & 1765 & 3777 \\
GG & 594 & 1051 & 72 & 0 & 489 & 0 & 1169 \\
HH & 2656 & 542 & 22 & 0 & 0 & 0 & 2714 \\
ROW & 314 & 550 & 69 & 0 & 0 & 200 & 1139 \\
Excess & 68 & 0 & 401 & 1500 & 0 & & \\
Financial asset & & & & & & & \\
Total & 5614 & 3777 & 768 & 2714 & 1139 & & \\
\hline
\end{tabular}

Source: created by authors using OECD.Stat data

Table 3 FFS Table for the U.S. (in units of 1 billion USD)

\begin{tabular}{llllllll}
\hline & FI & NFC & GG & HH & ROW & $\begin{array}{l}\text { Excess } \\
\text { liability }\end{array}$ & Total \\
\hline FI & 12,320 & 40,487 & 13,713 & 8775 & 11,197 & 1879 & 88,369 \\
NFC & 2229 & 8289 & 193 & 160 & 3576 & 32,998 & 57,014 \\
GG & 825 & 0 & 0 & 4430 & 137 & 15,571 & 20,963 \\
HH & 65,248 & 0 & 0 & 1003 & 0 & 0 & 66,251 \\
ROW & 7747 & 8238 & 7057 & 0 & & 0 & 23,043 \\
Excess & 0 & 0 & 0 & 51,883 & 5727 & & \\
Financial asset & & & & & & & \\
Total & 88,369 & 57,014 & 20,963 & 66,251 & 23,043 & & \\
\hline
\end{tabular}

Source: created by authors using OECD.Stat data

claims on GG and the ROW, which can be used to derive financial asset/liability ratios between FIs and these two sectors. In addition, the US net international investment statistics show the NFC and GG claims on the ROW. Using such information, judging issuing/holding sectors based on characteristics of financial instruments at the same time, and calculating $\mathrm{HH}$ assets/liabilities as a residual, we estimated a US FFS table.

In China, the People's Bank of China, which is China's central bank (CB), compiles and publishes the FFA but has not published a stock table. Given that China's stock table is indispensable for an Asia-Pacific FFS, the authors estimated such a table using various currently available financial data-for example, the Almanac of China's Finance and Banking for 2016, China Statistical Yearbook for 2017, Chinese Government Balance Sheet for 2017, and work by Tang (2018). Then, the authors converted this stock table into an FFS for China, as shown in Table 4. For a detailed discussion about estimating China's FFS table, refer to Appendix 1.

\subsection{Construction of international from-whom-to-whom financial stock table}

In this section, we summarize the framework and compilation methods of the global FFS table. An international FFS table combines several countries' FFS tables compiled from their FFAs, as shown in Fig. 2. The shaded regions of Fig. 2 represent claims/ obligations among domestic sectors. For identifying cross-border relationships or claims/obligations between domestic and foreign sectors, the ROW must be sub 
Table 4 FFS Table for China (in units of 1 billion USD)

\begin{tabular}{llllllll}
\hline & FI & NFC & GG & HH & ROW & $\begin{array}{l}\text { Excess } \\
\text { liability }\end{array}$ & Total \\
\hline FI & 4492 & 11,808 & 3058 & 639 & 3991 & 11,335 & 23,988 \\
NFC & 12,840 & 1651 & 243 & 0 & 395 & 18,276 & 15,129 \\
GG & 3964 & 11,574 & 1138 & 0 & 1610 & & 18,286 \\
HH & 16,296 & 1310 & 49 & 0 & 156 & & 17,811 \\
ROW & 1700 & 2112 & 258 & 0 & & 1675 & 4070 \\
Excess & & & 14,138 & 17,148 & & & \\
Financial asset & & & & & & & \\
Total & 27,956 & 10,178 & 18,884 & 17,788 & 4478 & & \\
\hline
\end{tabular}

Source: created by authors using Almanac of China's Finance and Banking in 2016, China Statistical Yearbook in 2017, Chinese Government Balance Sheet in 2017 and Tang (2018)

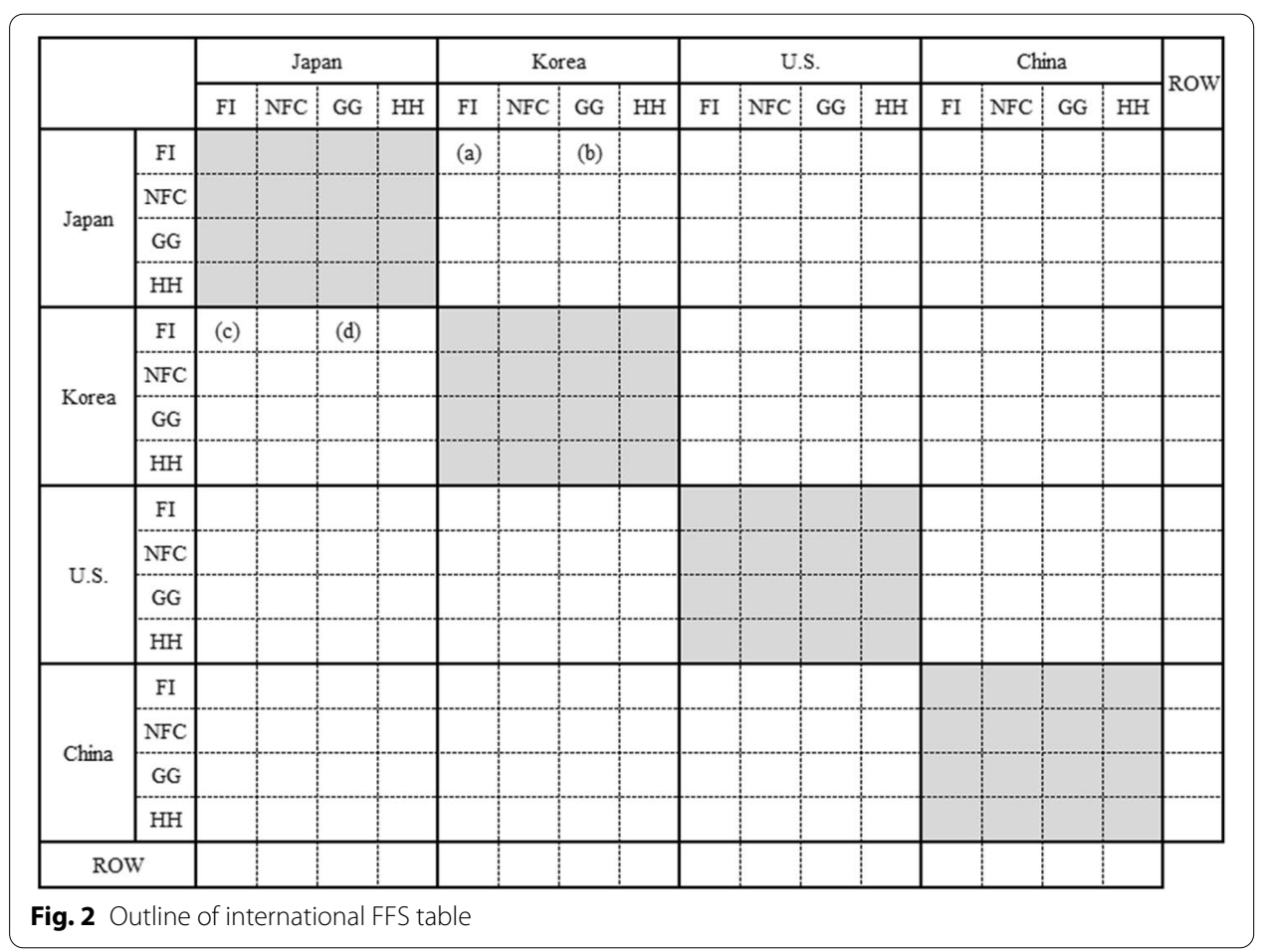

classified into Japan, Korea, the United States, and China, and then the four countries must be further subdivided into domestic sectors as partners. On the other hand, the nonshaded areas of Fig. 2 represent international transactions. More specifically, (a) in Fig. 2 represents claims of Japan's FIs on Korea's FIs, (b) represents claims of Japan's FIs on Korea's GG, (c) represents obligations of Japan's FIs to Korea's FIs, and (d) represents obligations of Japan's GG to Korea's FIs. In this table, ROW corresponds to partner countries other than Japan, Korea, the United States, and China.

To demonstrate cross-border claims/obligations, source data specifying "fromwhom-to-whom" sectors in such claim/obligation relations are necessary. For this purpose, net international positions and related statistics are useful. Net international 
positions refer to statistics representing the cross-border claims/obligations of a country or region. While balance of payments statistics record cross-border transactions and describe flows, net international positions describe stocks and correspond to balance sheets. In terms of their relationship with FFAs, cross-border claims/obligations represented in net international positions correspond to the ROW. While FFAs describe cross-border claims/obligations from the viewpoint of nonresidents of a country, net international positions describe claims/obligations from the viewpoint of residents. Because residents' claims correspond to nonresidents' liabilities, and residents' liabilities correspond to residents' claims, net international positions mirror those in FFAs.

Major countries publish net international positions by sector, and those reports supply strong source data for international FFS tables. However, the details of such data vary, particularly in terms of sector breakdowns of issuers/holders, making it difficult to incorporate such data into international FFS tables. In contrast, the IMF has developed internationally harmonized statistics for portfolio and direct investments, and it has published CPIS and CDIS. This paper has made use of such surveys, as their harmonized frameworks are quite useful. Incidentally, the IMF collects data on foreign reserve assets held by monetary authorities (central governments and CBs) and publishes the Securities Held as Foreign Exchange Reserves survey (SEFER). The results of the SEFER are incorporated into CPIS.

Given that international FFS tables combine FFS tables with sectors in both rows and columns, identifying partner countries is insufficient, and identifying the sectors in both home and partner countries is necessary. In this respect, the IMF has tried to develop data classified by home sectors and partner countries and cross-classify them in its enhanced CPIS. However, only a few countries provide data classified by sectors in partner countries. In addition, CDIS does not contain data classified by sectors. Therefore, for the time being, assumptions must be made about sector breakdowns. For example, this paper regards all cross-border direct investment positions as being among NFCs.

In terms of deposits and loans, the Bank for International Settlements (BIS) publishes cross-border positions by residence in its International Banking Statistics (IBS). Such data are useful for identifying partner countries when compiling international FFS tables. However, as BIS data are not broken down further by sector, this paper classifies all cross-border deposit/loan positions as being among FIs.

For portfolio investments, the authors prorated counterpart countries' claims/liabilities into sectors using the weight of total assets/liabilities by sector, while for deposits and loans, IBS data were adopted in the same manner as for the bilateral FFS table in Appendix 2.

To incorporate China into the international FFS, the authors applied the abovementioned treatment. In addition, given China's limited cross-border investment data, the authors gave attention to the following issues. China's CPIS data provide information on its outward portfolio investments (i.e., assets) by partner country. That data can be used to classify each sector's outward claims by counterpart country. In doing so, sector allocation in partner countries has been based on the total stock of each sector, except that outward HH claims are assumed to be those of FIs. In contrast, China's CDIS data do not provide information on outward direct investment by partner country. In addition, 
the IBS does not cover China. Under these circumstances, the only approach available is to allocate all outward claims, including direct and other investments, based on CPIS information.

When calculating China's inward investment (i.e., liabilities), its CPIS data do not provide information on inward portfolio investment by partner country. Thus, such investments are estimated using counterpart country data by partner country. US data, which includes data by sector in counterpart countries, are used to allocate inward investments to sectors in China. Other countries do not provide such data, and therefore, sector allocation in China is based on the total stock of each sector. In contrast, China's CDIS provides information about inward direct investment by partner country. Such liability data are recorded as claims/liabilities within the NFC sector. Other investments remain to be estimated, as the IBS does not cover China.

Table 5 displays an international FFS table covering Japan, Korea, the United States, and China. At a glance, Japan has relatively larger positions with the United States than with Korea and China, as shown in Table 5. Intuitively, positions between large economies tend to be large. Using this table, we can observe liability compositions vertically and asset compositions horizontally.

Figures 3 and 4 demonstrate the liability and financial asset portfolios of the four countries in 2015. The liabilities and financial assets of Fls of Japan are nearly the same, while the Fls of Korea, the United States, and China have positive excess liabilities. NFCs of Japan have relatively smaller excess liabilities than NFCs in other countries. The composition of the liabilities and financial assets of GGs differs from country to country.

For Korea's FI sector, investment in domestic FIs is the largest (40.9\%), while investment in GG is very small (2.6\%), as shown in Fig. 4. On the other hand, the domestic investment of Japan's FI sector is smaller than its foreign investment. Fund investment in the ROW is $50.3 \%$. Furthermore, investment in NFCs (11.0\%) is even less than in GG (14.6\%). This phenomenon is understandable given that Japan's interest rate is very low, and FIs are unwilling to invest in NFCs, preferring to invest in treasury bonds. Yoshino and Taghizadeh-Hesary (2016) pointed out that one of the causes of the slowdown in the Japanese economy is the unwillingness of Japanese banks to lend money to startup businesses and small and medium enterprises, mainly because of Basel capital requirements.

\subsection{Analytical methodology}

In this analysis, we apply the input-output analysis method devised by Tsujimura and Tsujimura (2008) to the FFS table for Japan, Korea, the United States, and China to examine the characteristics of financial positions among these countries. Specifically, we calculate a Leontief inverse matrix based on the table's liability and financial asset portfolio coefficients. Then, we calculate the power-of-dispersion and sensitivity-of-dispersion indexes.

First, the row and column totals of Table 5 must be identical. Differences are added to the smaller row or column total. In doing so, positions with countries other than the four focal countries, i.e., the ROW, are ignored. In this sense, the totals are the sum of the four countries' positions rather than the world totals. Liability and financial asset portfolio coefficients are calculated, representing the share of a certain country's and a certain sector's liability/financial asset position toward other sectors to the total positions of the four 


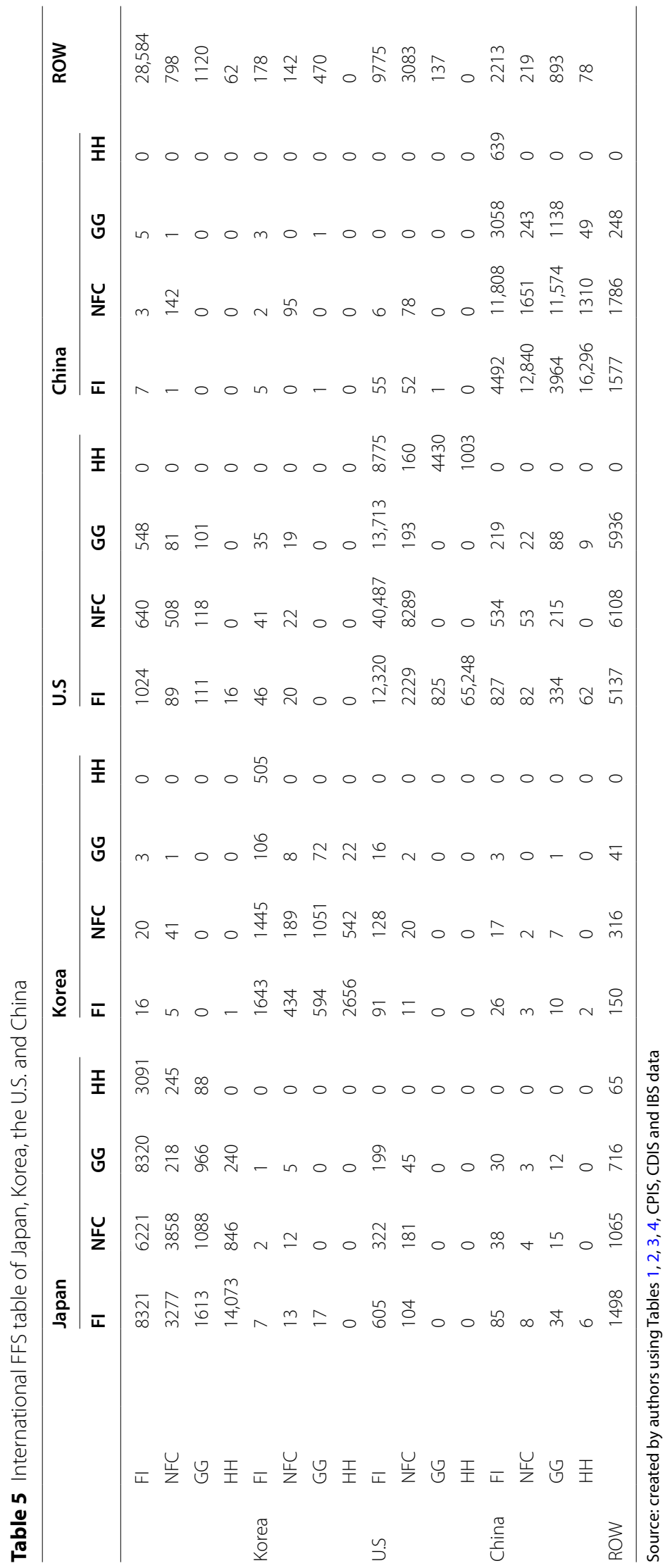



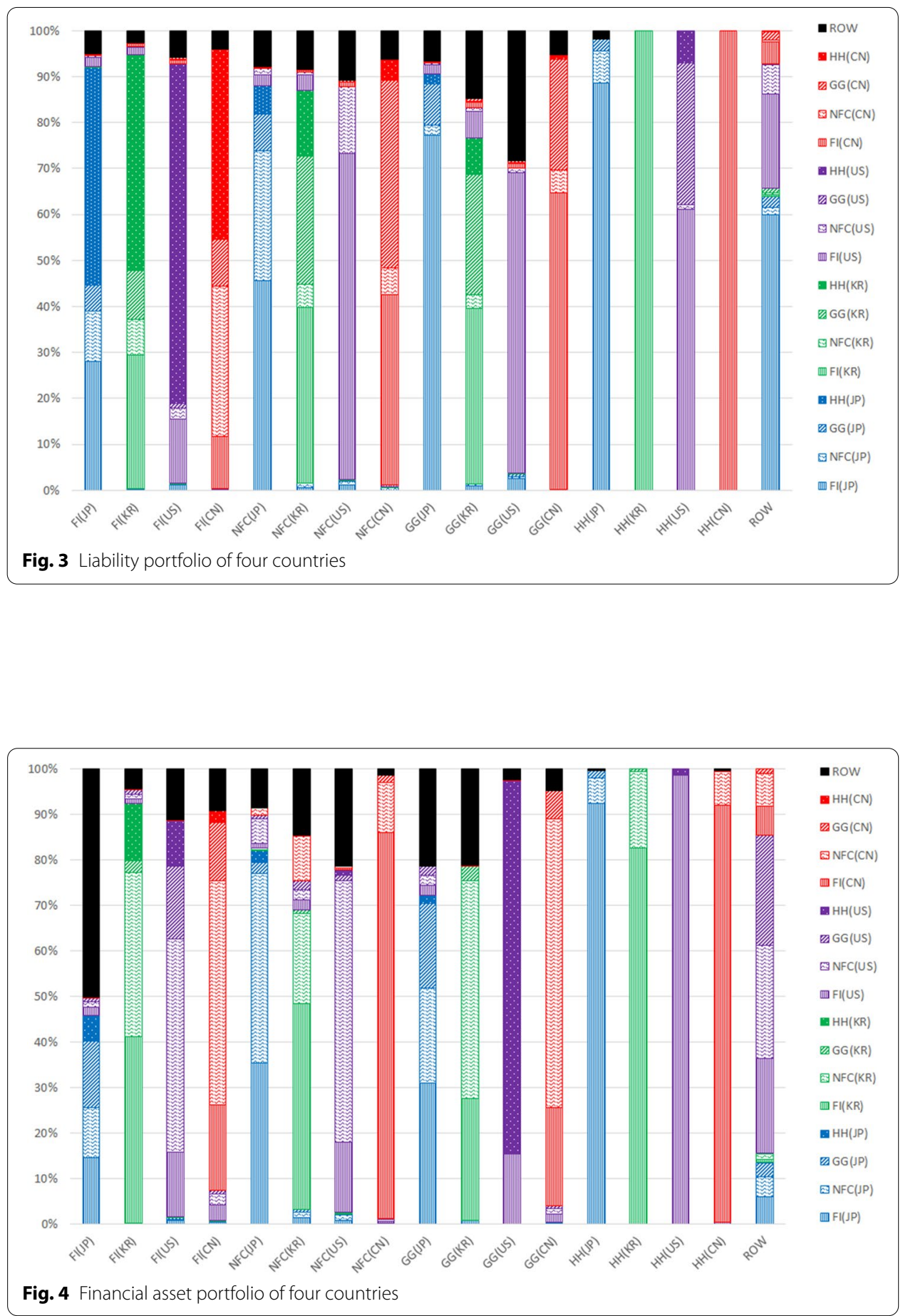

countries. Liability portfolio coefficients are obtained by calculating vertically. In contrast, financial asset portfolio coefficients are obtained by calculating horizontally. These coefficients correspond to the input coefficients of an input-output table. The international FFS table for Japan, Korea, the United States, and China is expressed as follows: 


$$
X=\left[\begin{array}{cccc}
x_{11} & x_{12} & \cdots & x_{1 n} \\
x_{21} & x_{22} & \cdots & x_{2 n} \\
\vdots & \vdots & \ddots & \vdots \\
x_{n 1} & x_{n 2} & \cdots & x_{n n}
\end{array}\right]
$$

where $n$ should be 16 in this case. By terming total liabilities, $t_{j}$, and total financial assets, $t_{i}$, the liability portfolio coefficients are defined as follows:

$$
l_{i j} \equiv \frac{x_{i j}}{t_{j}}
$$

and financial asset portfolio coefficients as follows:

$$
a_{i j} \equiv \frac{x_{i j}}{t_{i}}
$$

In this expression, $t_{i}$ (or $t_{j}$ ) is either the sum of the financial assets or liabilities of the $i$ th institutional sector, whichever is larger. Thus, liability coefficient matrix, $L$, and financial asset portfolio matrix, $A$, can be described as follows:

$$
\begin{gathered}
L=\left[\begin{array}{cccc}
l_{11} & l_{12} & \cdots & l_{1 n} \\
l_{21} & l_{22} & \cdots & l_{2 n} \\
\vdots & \vdots & \ddots & \vdots \\
l_{n 1} & l_{n 2} & \cdots & l_{n n}
\end{array}\right] \\
A=\left[\begin{array}{cccc}
a_{11} & a_{12} & \cdots & a_{1 n} \\
a_{21} & a_{22} & \cdots & a_{2 n} \\
\vdots & \vdots & \ddots & \vdots \\
a_{n 1} & a_{n 2} & \cdots & a_{n n}
\end{array}\right]
\end{gathered}
$$

Next, we apply the Leontief inverse to obtain the power-of-dispersion index. The fundamental equations are expressed as follows:

$$
\begin{aligned}
& L T+\varepsilon=T \\
& T^{\prime} A+\varphi=T^{\prime}
\end{aligned}
$$

where $\varepsilon$ means excess liability (if $\varepsilon_{i}>0$, where $\varepsilon_{i}=t_{i}-\sum_{j=1}^{n} x_{i j}$ ) -in other words, the difference between the sum of the financial assets or liabilities of the $i$ th institutional sector (whichever is larger) and total financial assets-whereas $\varphi$ represents excess financial assets (if $\varphi_{j}>0$, where $\varphi_{j}=t_{j}-\sum_{i=1}^{n} x_{i j}$ ), which means the difference between the sum of the financial assets or liabilities of the $j$ th institutional sector (whichever is larger) and total liabilities, as follows:

$$
T=\left[\begin{array}{c}
t_{1} \\
t_{2} \\
\vdots \\
t_{n}
\end{array}\right], \varepsilon=\left[\begin{array}{c}
\varepsilon_{1} \\
\varepsilon_{2} \\
\vdots \\
\varepsilon_{n}
\end{array}\right], \varphi^{\prime}=\left[\begin{array}{c}
\varphi_{1} \\
\varphi_{2} \\
\vdots \\
\varphi_{n}
\end{array}\right]
$$

Solving these equations in terms of $T$, we obtain 


$$
\begin{aligned}
& T=(I-L)^{-1} \varepsilon \\
& T^{\prime}=\varphi^{\prime}(I-A)^{-1}
\end{aligned}
$$

where $(I-L)^{-1}$ and $(I-A)^{-1}$ correspond to Leontief and Ghosh inverse coefficients. Matrices $\Gamma$ and $\Gamma^{*}$ are expressed as follows:

$$
\begin{gathered}
\Gamma=(I-L)^{-1}=\left[\begin{array}{cccc}
\gamma_{11} & \gamma_{12} & \cdots & \gamma_{1 n} \\
\gamma_{21} & \gamma_{22} & \cdots & \gamma_{2 n} \\
\vdots & \ddots & \vdots \\
\gamma_{n 1} & \gamma_{n 2} & \cdots & \gamma_{n n}
\end{array}\right] \\
\Gamma^{*}=(I-A)^{-1}=\left[\begin{array}{cccc}
\gamma_{11}^{*} & \gamma_{12}^{*} & \cdots & \gamma_{1 n}^{*} \\
\gamma_{21}^{*} & \gamma_{22}^{*} & \cdots & \gamma_{2 n}^{*} \\
\vdots & \ddots & \vdots \\
\gamma_{n 1}^{*} & \gamma_{n 2}^{*} & \cdots & \gamma_{n n}^{*}
\end{array}\right]
\end{gathered}
$$

Using $\gamma_{i j}$ and $\gamma_{i j}^{*}$, the power-of-dispersion index in the liability-oriented system, $\omega_{j}$, and the asset-oriented system, $\omega_{j}^{*}$, and the sensitivity-of-dispersion index in the liability-oriented system, $z_{i}$, and the asset-oriented system, $z_{i}^{*}$, are defined as follows:

$$
\begin{aligned}
& \omega_{j}=\frac{\sum_{i=1}^{n} \gamma_{i j}}{\frac{1}{n} \sum_{j=1}^{n} \sum_{i=1}^{n} \gamma_{i j}} \\
& \omega_{j}^{*}=\frac{\sum_{j=1}^{n} \gamma_{i j}^{*}}{\frac{1}{n} \sum_{i=1}^{n} \sum_{j=1}^{n} \gamma_{i j}^{*}} \\
& z_{i}=\frac{\sum_{j=1}^{n} \gamma_{i j}}{\frac{1}{n} \sum_{i=1}^{n} \sum_{j=1}^{n} \gamma_{i j}} \\
& z_{j}^{*}=\frac{\sum_{i=1}^{n} \gamma_{i j}^{*}}{\frac{1}{n} \sum_{j=1}^{n} \sum_{i=1}^{n} \gamma_{i j}^{*}}
\end{aligned}
$$

The power-of-dispersion index in the liability-oriented system measures the relative extent to which a unit increase in demand for capital of a given sector is dispersed throughout the financial system. Meanwhile, the power-of-dispersion index in the assetoriented system describes the increase in the final supply to the system of industries in general as driven by a unit increase in the capital supply of a given sector. The sensitivity-of-dispersion index in the liability-oriented system explains the capital raised within a given institutional sector, which is directly or indirectly driven by a unit increase in the final borrowing for all sectors in the system. In contrast, the sensitivity-of-dispersion index in the asset-oriented system expresses the extent to which money can be supplied to a given institutional sector, directly or indirectly driven by a unit increase in the final lending for all institutional sectors in the system. 


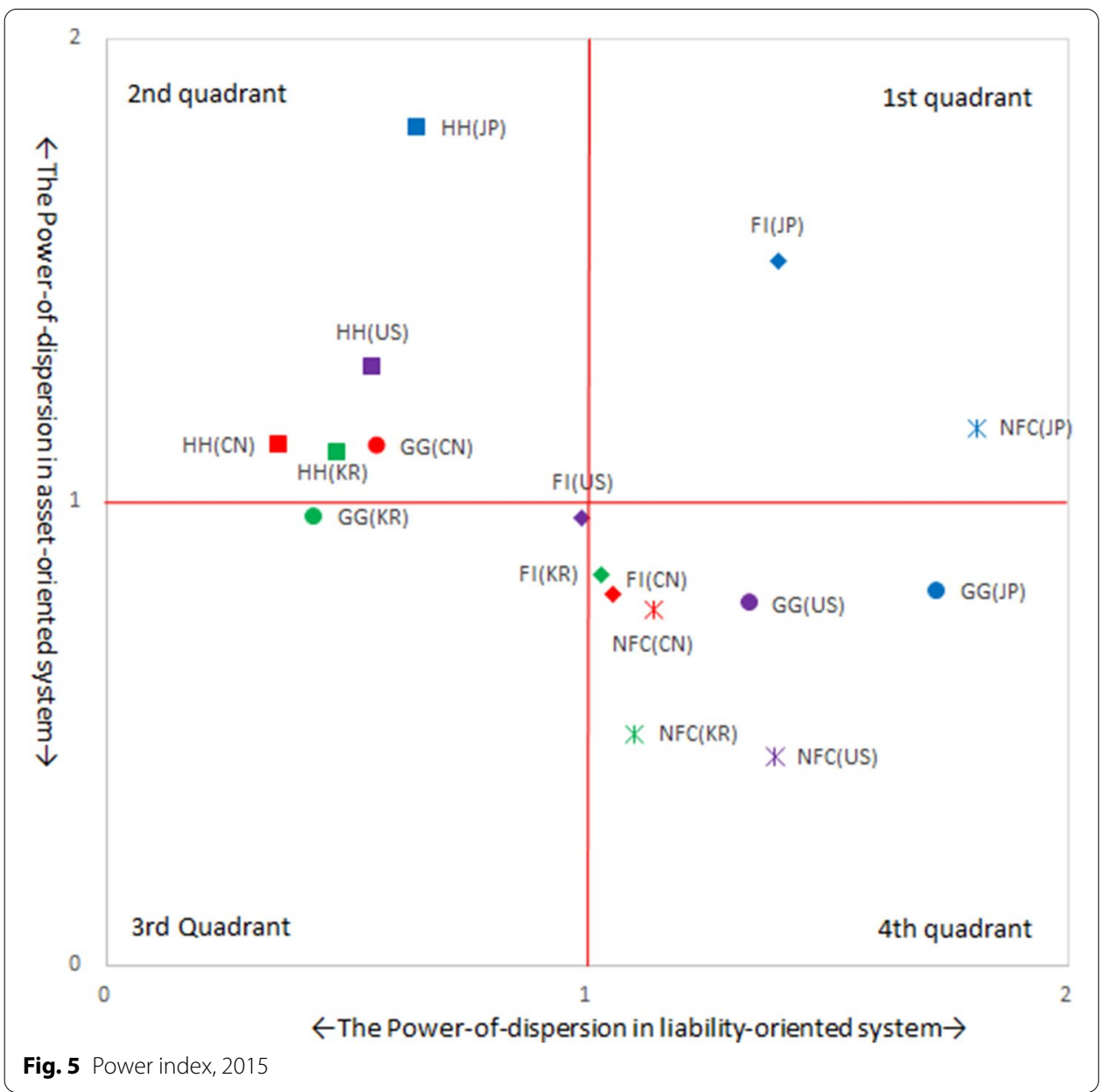

\section{Results and discussion}

Figures 5 and 6 display the power-of-dispersion and sensitivity-of-dispersion indexes for the four countries in 2015. The baseline for the index used to measure the extent of dispersion is 1 . The major benefit of these indices is that they enable the identification of the relative position of each sector in the financial market where the sectors are interdependent on one another directly or indirectly. The index in the liability-oriented system is shown in the rows, while the index in the asset-oriented system is shown in the columns. Each sector is placed in a four-quadrant graph.

In Fig. 5, the $\mathrm{HH}$ sector, whose financial assets exceed liabilities, is generally positioned in the second quadrant because $\mathrm{HHs}$ exercise greater power over assets and less power over liabilities. In contrast, the GG and NFC sectors, whose liabilities exceed financial assets, are generally placed in the fourth quadrant, with limited asset power but extensive liability power. NFCs have the most liability power within the four countries. Consequently, the NFCs of three of the countries are shown in the fourth quadrant. Meanwhile, Japan's NFCs are positioned within the first quadrant because Japan has a high degree of power over its assets. 


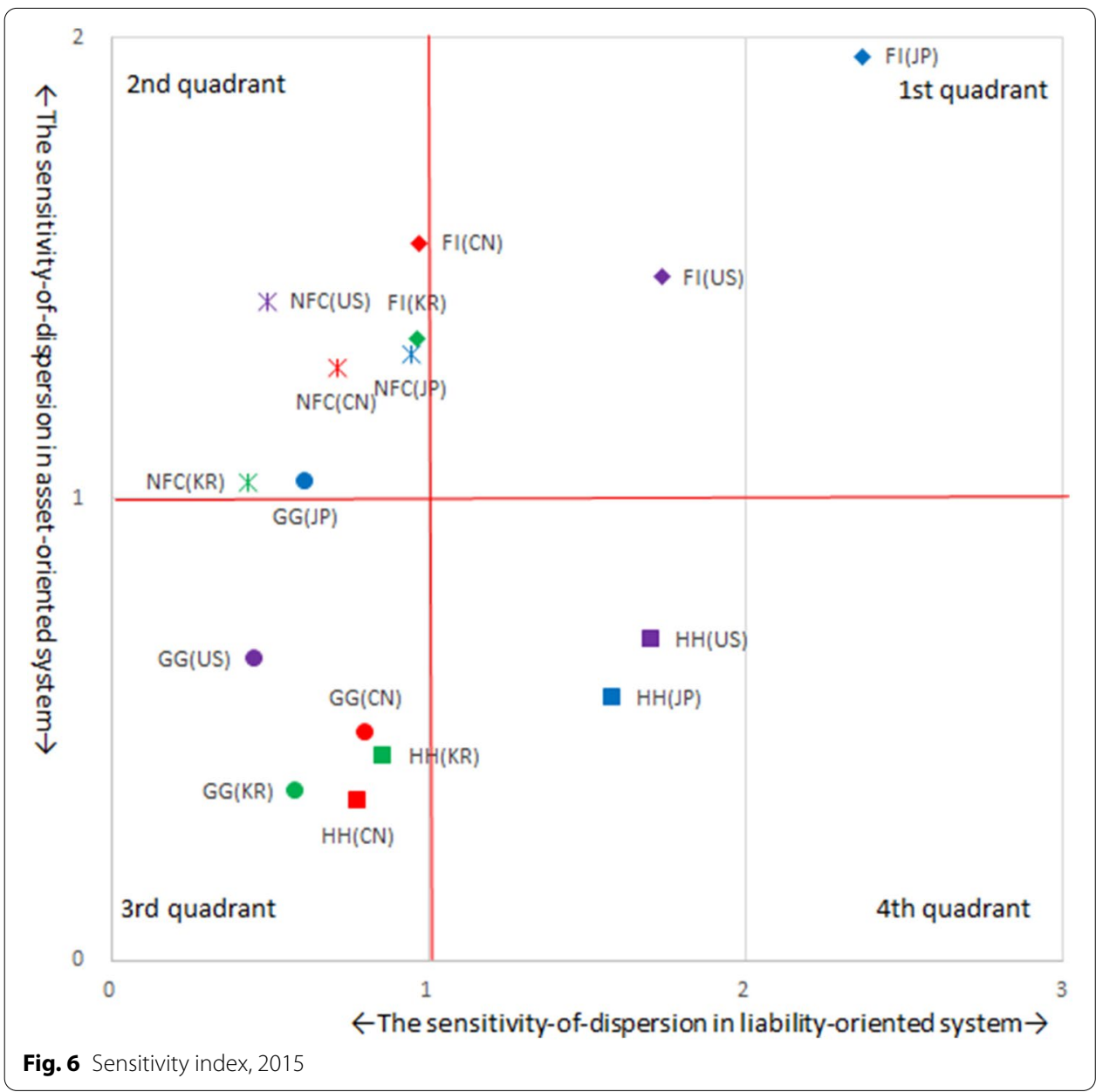

According to Kim (2013), the power index in the asset-oriented system of NFCs has steadily increased in Japan, finally exceeding standards after 2010. Kim (2013) explains that NFCs in Japan reduced investment in equipment to instead focus on financial investment, giving rise to the increase in the power index in the asset-oriented system. Similarly, the GGs of Japan and the United States are in the fourth quadrant. Conversely, the GG of China is in the second quadrant, with the HHs and GG of Korea in the third quadrant. Especially, the GG of Japan has relatively large liability power that reflects Japan's large outstanding GG liabilities. The FI sector, which intermediates asset-exceeding sectors with liability-exceeding sectors, is placed around one for Korea, the United States, and China. In contrast, the FIs of Japan are placed in the first quadrant. This placement indicates that the power of FIs in Japan is relatively enormous for both assets and liabilities.

Figure 6 demonstrates the sensitivity-of-dispersion index. FIs have the largest liability sensitivity in Japan, Korea, and China, while the HH sector is the biggest in the United States, which appears to reflect the large outstanding HH liabilities in the United States. FIs are positioned in the first quadrant for Japan and the United States, meaning that FIs in these countries are very sensitive. GG is generally positioned in 


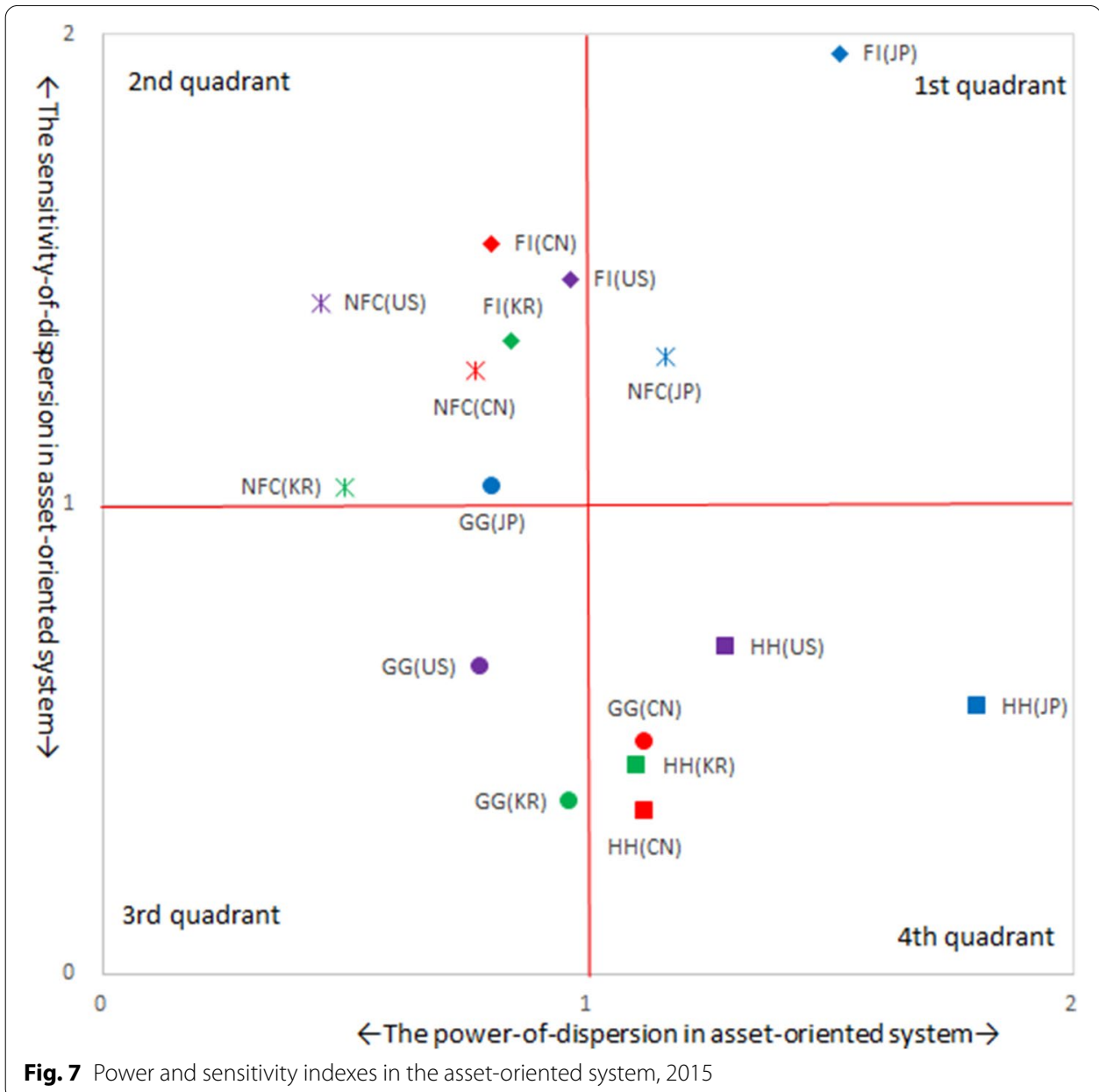

the third quadrant, representing small sector sensitivity, though the GG of Japan is placed in the second quadrant.

To focus on the influence of financial assets, Fig. 7 demonstrates only indices in an asset-oriented system. The power-of-dispersion index is in the rows, while the sensitivity-of-dispersion index is in the columns. Features of the FIs, NFCs, and GG in Japan are different from those of the other countries in Fig. 7. The FIs and NFCs of Japan are placed in the first quadrant, while the FIs and NFCs of other countries are in the second quadrant. Similarly, the GG of Japan is settled in the second quadrant, the GG of the United States and Korea are in the third quadrant, and the GG of China is in the fourth quadrant.

\section{Concluding remarks}

This paper has discussed the compilation of an international FFS table for Japan, Korea, the United States, and China by connecting individual countries' FFS tables. We applied an input-output analysis to the international FFS table to identify characteristics of positions among these four countries. This study provides momentum to the international development of global FFAs. 
Our study has applied traditional input-output analysis, and thus, further study is necessary for more profound analyses. In addition, our focus is on the stock table. Relatively stable portfolio coefficients enable us to apply an input-output analysis. Once fromwhom-to-whom flow tables, which may have less stable portfolio coefficients, become available, we will have to examine the method applicable to each such table.

As to the future of the international FFS table, we would like to expand the coverage by including other major countries of the Asia-Pacific Region, such as Thailand, Indonesia, Mexico, and Brazil. Another future direction would be to combine the Asia-Pacific table with the Euro-area table, which the European CB compiles, and thus transform the international table into a global one.

Also, we would like to examine how to improve the quality of our international FFS table by incorporating newly available official statistics. For example, the CBs of Japan, Korea, the United States, and China are working on an FFS table to comply with the IMF's SDDS Plus. Thus, it is expected that such tables will be available soon. As for the CPIS, it is expected that international investment data will be cross-classified by sector in home and counterpart countries. We would like to update our table as such newly developed data become available.

\section{Appendix 1: Estimation of China's from-whom-to-whom financial stock table}

China's HH financial assets have been estimated until the end of 2014 (see Table 6) based on the HH surveys in China (Li et al. 2015) introduced by Tang (2018). By adding flows in 2015, we can broadly estimate the stocks at the end of 2015, although we cannot reflect revaluations of shares and so on in the stocks. In doing so, currency and deposits are classified into deposits, bonds are classified into debt securities, and insurance reserves are classified into IPs without further examination. In contrast, trust funds should be examined, but we classified them as investment trusts and counted them as shares and other equity. "Fund" in China refers to private placement funds and hedge funds invested by HHs, in which wealth management products and trust products are included. Wealth management products are banks' off-balance-sheet liabilities, and trust products are trust companies' liabilities. They are referred to as China's shadow

Table 6 China's financial assets (in units of \% for ratios, 100 million CNY for amounts)

\begin{tabular}{llllllll}
\hline & $\begin{array}{l}\mathbf{2 0 0 4} \\
\text { (ratio) }\end{array}$ & $\begin{array}{l}\mathbf{2 0 0 6} \\
\text { (ratio) }\end{array}$ & $\begin{array}{l}\mathbf{2 0 0 8} \\
\text { (ratio) }\end{array}$ & $\begin{array}{l}\mathbf{2 0 1 0} \\
\text { (ratio) }\end{array}$ & $\begin{array}{l}\mathbf{2 0 1 2} \\
\text { (ratio) }\end{array}$ & $\begin{array}{l}\mathbf{2 0 1 4} \\
\text { (ratio) }\end{array}$ & $\begin{array}{l}\mathbf{2 0 1 4} \\
\text { (amount) }\end{array}$ \\
\hline Currency & 9.9 & 8.9 & 8.3 & 7.6 & 6 & 5.6 & 57,792 \\
Deposits & 71.8 & 68.3 & 66.6 & 63.8 & 55.4 & 49.1 & 506,713 \\
Bonds & 3.5 & 2.8 & 1.5 & 0.5 & 0.6 & 0.5 & 5160 \\
Pension reserves & 7.8 & 9 & 11 & 10.6 & 9.5 & 10.2 & 105,264 \\
Shares & 4.9 & 6.8 & 5.9 & 11.4 & 8.1 & 7.7 & 79,464 \\
Fund & 1.1 & 2.2 & 5 & 1.5 & 1.5 & 0.9 & 9288 \\
Guarantee deposits & 0.7 & 1.2 & 1.4 & 0.9 & 0.3 & 0.1 & 1032 \\
Wealth management Products & 0 & 0 & 0 & 3 & 8.8 & 13.4 & 138,288 \\
Trust products & 0.2 & 0.8 & 0.3 & 0.6 & 9.8 & 12.4 & 127,968 \\
Total amount & 180,369 & 251,600 & 342,870 & 494,832 & 761,964 & $1,032,002$ & $1,030,970$ \\
\hline
\end{tabular}

Source: Li et al. (2015) and Tang (2018) 
Table 7 Estimation of HHs and debt securities (in units of 100 million USD)

\begin{tabular}{|c|c|c|c|c|c|c|c|c|c|c|}
\hline & \multicolumn{2}{|l|}{$\mathrm{FI}$} & \multicolumn{2}{|c|}{ NFC } & \multicolumn{2}{|c|}{ GG } & \multicolumn{2}{|l|}{$\mathrm{HH}$} & \multicolumn{2}{|c|}{ ROW } \\
\hline & A & $\mathbf{L}$ & A & $\mathbf{L}$ & A & $\mathbf{L}$ & A & $\mathbf{L}$ & $A$ & L \\
\hline Deposits & & & & & & & 9450 & & & \\
\hline Debt securities & & 188,818 & & 144,152 & & 154,524 & 156 & & & \\
\hline Loans & & & & & & & & 4122 & & \\
\hline Equity & & & & & & & 5656 & & & \\
\hline and shares & & & & & & & & & & \\
\hline IPs & & & & & & & 1844 & & & \\
\hline Derivatives & & & & & & & & & & \\
\hline Others & & & & & & & 682 & & & \\
\hline Total & & & & & & & 17,788 & 4122 & & \\
\hline Difference & & & & & & & & 13,666 & & \\
\hline
\end{tabular}

Source: created by authors using credit to the non-financial sector published by the BIS. A: assets; L: liabilities

banking, which has developed very rapidly. Funds in China have different characteristics from bank deposits in that their returns and risks are larger than bank deposits. In many countries, financial products with such characteristics are treated as investment trust shares, and therefore, we applied a similar treatment to funds in China.

For HH liabilities, we used data on credit to the nonfinancial sector published by the BIS. According to these statistics, FI claims on HHs amount to 26,564 billion USD, of which claims on HHs (including nonprofit institutions serving as HHs) amount to 4122 billion USD (26,330 billion Chinese yuan, or CNY). We recorded such claims as loans to HHs, as shown in Table 7. The amounts of debt securities issued in China are published with the details of government bonds, CB bonds, FI bonds, and NFC bonds (combinations of corporate bonds, convertible bonds, and so forth), which can be linked to sectors in the FFA. In contrast, the amounts of local government and nonresident bonds remain to be estimated in the process of estimating the financial assets/liabilities of the GG and ROW sectors, respectively. HH financial assets and liabilities have been estimated from the abovementioned processes, and the debt securities issuances of FIs, NFCs, and GGs can be recorded as preliminary estimates. For the debt security issuance of the NFC sector, for which balance sheet data do not exist, such preliminary estimations become the final figure, where those of the NFC and GG sectors are replaced in the process of using their balance sheet data.

In China, the State Administration of Foreign Exchange publishes international investment positions (IIPs), which can be used as financial assets/liabilities of the ROW. It should be noted that an FFA describes cross-border claims/obligations from the viewpoint of nonresidents of a country (who are counterparts of residents), while net international positions describe claims/obligations from the viewpoint of residents. Thus, residents' claims on IIPs are recorded as ROW liabilities in an FFA, and residents' liabilities to IIPs are recorded as ROW claims in an FFA. As to financial asset/liability items, most direct investments are in shares and can be classified as shares and other equity. In contrast, portfolio investments include debt securities and shares, and other investments include deposits and loans. Official reserves include at least debt securities and loans. Splitting these items into detailed categories is ideal, but source data do not always allow 
for this. We, therefore, classified portfolio investments and official reserves as debt securities and other investments as loans. As a result, USD-denominated financial assets/ liabilities of the ROW sector can be estimated. Incidentally, HH holdings and NFC debt securities issuances are finalized in USD by converting by the foreign exchange rate at the end of 2015.

For the FI sector, the People' Bank of China publishes the balance sheet of the CB and other depository corporations (ODCs, commercial banks) within the framework of IMF monetary and financial statistics as the CB survey and the deposit money bank survey, respectively. These surveys are posted in the Almanac of China's Finance and Banking 2016. In addition, balance sheets of insurance companies, classified as IPs in the FFA, and the balance sheets of securities and trust companies, classified as other financial corporations, are posted in the bulletin. By aggregating these balance sheets, the financial assets/liabilities of FIs should be identified. However, there are some issues to examine.

For depository corporations, assets are classified by counterpart sector in surveys of the $\mathrm{CB}$ and ODCs (commercial banks). Although such data are useful in compiling an FFS, as discussed later, we face source data shortcomings when compiling the FFAs to identify financial asset/liability items. For CBs, we classified the survey's claims on GGs and the ROW as debt securities and the survey's claims on FIs and other private sectors as loans in the absence of source data. For ODCs (commercial banks), we used the balance sheets of major banks posted in the Almanac of China's Finance and Banking 2016 for splitting financial asset/liability items. However, this type of balance sheet is based on commercial accounting rules, which attach importance to holding purposes. Although long-term equity investments can be classified as shares and equity in an FFA, held-tomaturity and tradable investments could be debt securities or shares and other equity. In the absence of source data for splitting these two types of investments into two items, we classified them as debt securities while considering their terms to maturity.

For insurance, securities, and trust companies, financial assets/liabilities are obtained using a consolidated balance sheet or by aggregating individual balance sheets. However, assumptions must be made in splitting securities into debt securities or shares and other equity in the same way as the estimation of ODCs. In addition, it appears that the coverage of shadow banking, such as trust companies, is not sufficient in the China Financial Bulletin 2016. Therefore, we added funds held by HHs and wealth management and trust financial asset products to investment fund shares issued by other financial intermediaries. For assets, we assumed that $60 \%$ is lent out as loans and $40 \%$ is invested in debt securities. As a result of such estimation, financial assets/liabilities of the FI sector with the breakdown of its subsector can be identified in CNY as shown in Table 8, and the sector's aggregated amount is converted into USD using the foreign exchange rate at the end of 2015 in Table 9.

For the GG sector, deposits (assets) and debt securities (liabilities) have been specified in the process of estimating other sectors and financial assets/liabilities items. However, other items, as well as the financial assets/liabilities of local governments, remain to be estimated. In this respect, there are no official statistics on the financial assets/liabilities of GG. However, we have used the Chinese Academy of Social Sciences estimates on the Chinese government's financial assets/liabilities as of the end of 2015, which are published in the Chinese Government Balance Sheet in 2017. For financial assets, we 


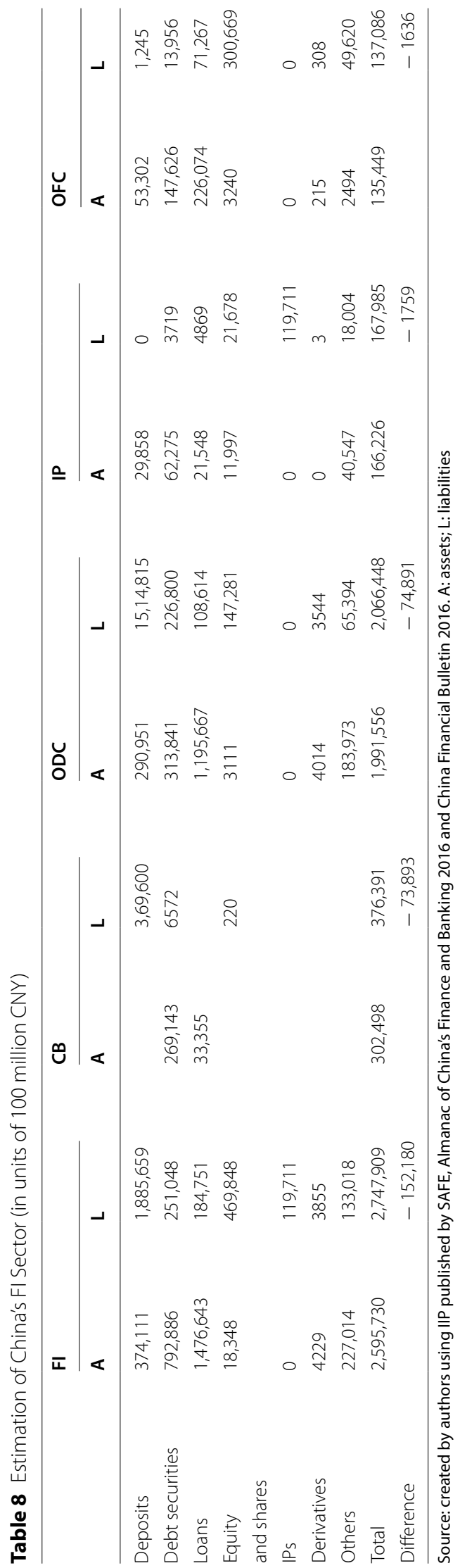


Table 9 Estimation of China's HH, ROW and FI Sectors and debt securities (in units of 1 billion USD)

\begin{tabular}{|c|c|c|c|c|c|c|c|c|c|c|}
\hline & \multicolumn{2}{|l|}{$\mathrm{FI}$} & \multicolumn{2}{|c|}{ NFC } & \multicolumn{2}{|c|}{ GG } & \multicolumn{2}{|l|}{$\mathrm{HH}$} & \multicolumn{2}{|l|}{ ROW } \\
\hline & A & L & A & $\mathbf{L}$ & A & L & A & L & A & $\mathbf{L}$ \\
\hline Deposits & 5763 & 29,048 & & & & & 9450 & & & \\
\hline Debt securities & 15,499 & 3867 & & 2221 & & & 156 & & 817 & 3667 \\
\hline Loans & 22,747 & 2846 & & & & & & 4122 & 964 & 1389 \\
\hline $\begin{array}{l}\text { Equity } \\
\text { and shares }\end{array}$ & 3568 & 7238 & & & & & 5656 & & 2696 & 1096 \\
\hline IPs & 0 & 1844 & & & & & 1844 & & & \\
\hline Derivatives & 65 & 59 & & & & & & & & \\
\hline Others & 3497 & 2049 & & & & & 682 & & & \\
\hline Total & 39,987 & 42,331 & & & & & 17,788 & 4122 & 4478 & 6152 \\
\hline Difference & & -2344 & & & & & & 13,666 & & 1673 \\
\hline
\end{tabular}

Source: created by authors using IIP published by SAFE, Almanac of China's Finance and Banking 2016 and China Financial Bulletin 2016. A: assets; L: liabilities

Table 10 Estimation of China's HH, Fl and GG Sectors and debt securities (in units of 100 million (NY)

\begin{tabular}{|c|c|c|c|c|c|c|c|c|}
\hline & \multicolumn{2}{|l|}{$\mathrm{FI}$} & \multicolumn{2}{|c|}{ NFC } & \multicolumn{2}{|l|}{ GG } & \multicolumn{2}{|l|}{$\mathrm{HH}$} \\
\hline & A & $\mathbf{L}$ & A & $\mathbf{L}$ & $A$ & $\mathbf{L}$ & A & $\mathbf{L}$ \\
\hline Deposits & 374,111 & $1,885,659$ & & & 27,179 & & 613,424 & \\
\hline Debt securities & 792,886 & 251,048 & & 144,152 & 233,533 & 243,065 & 10,098 & \\
\hline Loans & $1,476,643$ & 184,751 & & & & 15,205 & & 267,580 \\
\hline $\begin{array}{l}\text { Equity } \\
\text { and shares }\end{array}$ & 18,348 & 469,848 & & 715,261 & 457,651 & & 367,154 & \\
\hline IPS & & 119,711 & & & & & 119,711 & \\
\hline Derivatives & 4229 & 3855 & & & & & & \\
\hline Others & 227,014 & 133,018 & & & & & 44,297 & \\
\hline Total & $2,595,730$ & $2,747,909$ & & & 718,364 & 258,270 & $1,154,684$ & 267,580 \\
\hline Difference & & $-152,180$ & & & & & & \\
\hline
\end{tabular}

Source: created by authors using Chinese Government Balance Sheet in 2017. A: assets; L: liabilities

recorded the equity in state-owned corporations as shares and equity. After deducting shares and equity as well as already estimated deposits from total assets, we regarded the residual as debt securities. As for liabilities, the issue is how to split local governments' direct liabilities into debt securities and loans. According to research on local government debt in China, until 2013, loans were a primary fundraising tool. After the modification of China's budget law in 2014, however, fundraising was also accomplished using debt securities. Considering that the weight of debt securities has been increasing, we classified $60 \%$ of their direct liabilities as debt securities and $40 \%$ as loans. The resulting financial assets/liabilities of the GG sector and those of the HH and FI sectors have been identified on a CNY basis, as shown in Table 10.

The total market capitalization in China as of the end of 2015 is published in the Almanac of China's Finance and Banking 2016. From this amount, we deducted the value of shares issued by FIs, which is derived from their balance sheets and added to government equity in state-owned enterprises. We regarded this amount as shares issued by the NFC sector. The total shares issued by the FI sector are the sum of shares issued by 
Table 11 FFA Stock Table after Adjusting Negative Figures (in units of 1 billion USD)

\begin{tabular}{|c|c|c|c|c|c|c|c|c|c|c|}
\hline & \multicolumn{2}{|l|}{$\mathrm{FI}$} & \multicolumn{2}{|l|}{ NFC } & \multicolumn{2}{|l|}{ GG } & \multicolumn{2}{|l|}{$\mathrm{HH}$} & \multicolumn{2}{|l|}{ ROW } \\
\hline & A & L & A & L & A & L & A & L & A & $\mathrm{L}$ \\
\hline Deposits & 5763 & 29,048 & 13,417 & & 419 & & 9450 & & & \\
\hline Debt securities & 8929 & 3867 & 0 & 2221 & 3598 & 3744 & 156 & & 817 & 3667 \\
\hline Loans & 22,747 & 2846 & & 15,120 & & 234 & & 4122 & 964 & 1389 \\
\hline $\begin{array}{l}\text { Equity } \\
\text { and shares }\end{array}$ & 3568 & 7238 & 382 & 11,018 & 7050 & & 5656 & & 2696 & 1096 \\
\hline IPs & & 1844 & & & & & 1844 & & & \\
\hline Derivatives & 65 & 59 & & 6 & & & & & & \\
\hline Others & 3497 & 2049 & & 2130 & & & 682 & & & \\
\hline Total & 39,987 & 42,331 & 13,799 & 30,496 & 11,066 & 3979 & 17,788 & 4122 & 4478 & 6152 \\
\hline Difference & & -2344 & & $-16,696$ & & 7088 & & 13,666 & & 1673 \\
\hline
\end{tabular}

Source: created by authors using the Almanac of China's Finance and Banking 2016. A: assets; L: liabilities

FIs, which were derived from their balance sheet, and investment fund shares held by HHs, which were estimated during the initial process.

We calculated the amounts of financial asset/liability items not yet estimated residually by deducting already estimated amounts from the total amount. In this way, deposits, debt securities, shares, and equity appear on the asset side, while loans are on the liability side. As a result, the holdings of debt securities become negative. We, therefore, reexamined the estimation processes. We conclude that the residual becomes negative due to overestimating FI holdings of debt securities. This amount was estimated by aggregating balance sheet data. As explained above, balance sheet data are based on commercial accounting rules, which emphasize holding purposes. In the absence of detailed source data, we regarded both held-to-maturity and tradable investments as debt securities. If this is true, FI holdings of debt securities should be decreased, and the corresponding amount should be added to shares and other equity. We set the adjustment amount to the level that makes NFC holdings of debt securities (3285 billion USD) zero rather than negative. In this way, we have developed an FFA stock table without negative figures, as shown in Table 11.

The abovementioned FFA stock data table, which has a matrix form with sectors in columns and financial assets/liabilities in rows, cannot represent counterpart sectors in the matrix table. Therefore, it cannot show asset/liability or claim/obligation relationships among sectors. In contrast, an FFS, which uses a square matrix with economic sectors in both columns and rows, can demonstrate the claim/obligation relationship (and flow of funds as necessary) among sectors, as Hagino et al. $(2018,2019)$ explained in more detail.

To compile an FFS for China, information on counterpart sectors is needed. In this respect, there are financial asset/liability items for which counterpart sectors are evident from their characteristics. For example, deposits are assumed, and loans are held by FIs. IPs and investment trusts are generally held by HHs. Financial derivatives are held and assumed mostly by FIs. Thus, financial asset/liability stocks for which counterpart sectors can be identified are shown in Table 12. In contrast, counterpart sectors cannot be identified for debt securities and shares. Globally speaking, 
Table 12 Financial Asset/Liability Stocks for which Counterpart Sectors can be Identified (in units of 100 million CNY)

\begin{tabular}{|c|c|c|c|c|c|c|c|c|c|}
\hline & $\mathrm{FI}$ & $\mathrm{CB}$ & ODC & IP & OFC & NFC & GG & $\mathrm{HH}$ & Row \\
\hline $\mathrm{Fl}$ & & & & & & 981,920 & 15,205 & 267,580 & 90,160 \\
\hline \multicolumn{10}{|l|}{$C B$} \\
\hline ODC & & & & & & 981,920 & 15,205 & 267,580 & 90,160 \\
\hline \multicolumn{10}{|l|}{ IP } \\
\hline \multicolumn{10}{|l|}{ OFC } \\
\hline NFC & 870,946 & & 870,946 & & & & & & \\
\hline GG & 106,729 & 27,179 & 79,550 & & & 378,102 & & & \\
\hline $\mathrm{HH}$ & $1,017,607$ & & 613,424 & 119,711 & 284,472 & & & & \\
\hline ROW & 62,598 & & 62,598 & & & & & & \\
\hline
\end{tabular}

Source: created by authors. A: assets; L: liabilities

Table 13 Financial Asset/Liability Stocks for which Counterpart Sectors cannot be Identified (in units of 100 million CNY)

\begin{tabular}{llllllll}
\hline & FI & NFC & GG & HH & ROW & $\begin{array}{l}\text { Difference } \\
(\mathbf{L}>\mathbf{A})\end{array}$ & Total \\
\hline FI & 291,576 & 295,265 & 183,304 & 0 & 168,888 & \\
NFC & 39,269 & 107,154 & 15,759 & 0 & 25,646 & \\
GG & 150,605 & 373,196 & 73,851 & 0 & 104,540 & \\
HH & 40,227 & 85,008 & 3193 & 0 & 10,136 & \\
ROW & 47,765 & 137,083 & 16,772 & 0 & & \\
Difference (A>L) & & & & & & \\
Total & & & & & & \\
\hline
\end{tabular}

Source: created by authors. A: assets; L: liabilities.

Table 14 CNY-based FFS for China (in units of 100 million CNY)

\begin{tabular}{llllllll}
\hline & FI & NFC & GG & HH & ROW & Difference (L>A) & Total \\
\hline FI & 291,576 & 766,545 & 198,508 & 41,497 & 259,048 & 735,835 & $1,557,175$ \\
NFC & 833,525 & 107,154 & 15,759 & 0 & 25,646 & $1,186,361$ & 982,083 \\
GG & 257,333 & 751,297 & 73,851 & 0 & 104,540 & & $1,187,022$ \\
HH & $1,057,834$ & 85,008 & 3193 & 0 & 10,136 & & $1,156,171$ \\
ROW & 110,362 & 137,083 & 16,772 & 0 & & 108,707 & 264,217 \\
Difference (A>L) & & & 917,746 & $1,113,187$ & & & \\
Total & $1,814,796$ & 660,726 & $1,225,828$ & $1,154,684$ & 290,663 & & \\
\hline
\end{tabular}

Source: created by authors. A: assets; L: liabilities

some countries have developed a comprehensive security-by-security database and can identify securities' issuing and holding sectors. China has not provided such data. For financial assets/liabilities whose issuing and holding sectors cannot be identified, a method of prorating to sectors based on the weight of each sector's total financial asset/liability stocks was used, and the results are listed in Table 13.

By combining financial asset/liability stocks for which counterpart sectors can be identified and those for which counterpart sectors cannot be identified, Table 14 is 
produced in the same way financial subsectors are consolidated. Table 4 is converted to a USD basis using the foreign exchange rate at the end of 2015 .

\section{Appendix 2: Estimation of Bilateral From-Whom-To-Whom Financial Stock Table}

CPIS data for Japan and Korea contain sector breakdowns for the home countries but not for partner countries. Thus, the assets of a home country sector were allocated to partner country sectors based on ratios of the entire liability amounts by sector in partner countries. CPIS data for Japan and Korea are incorporated into an international FFS table that is shown as Table 15. Because CPIS data for Japan and Korea do not contain sector breakdowns for home and partner countries, direct investments were classified as among NFCs. In addition, data for Korea do not identify direct investments to Japan. Thus, this paper used Japan's inward and outward data to cover this absence in data for Korea. Such data are shown as positions among NFCs between the two countries in Table 16. As for deposit/loan positions between the two countries, data are available in Japan's and Korea's IBSs. Such data are shown as positions among FIs between the two countries, as shown in Table 16. If these sources are

Table 15 Incorporation of CPIS data for Japan and Korea into the International FFS Framework (in units of 1 billion USD)

\begin{tabular}{|c|c|c|c|c|c|c|c|c|c|}
\hline & & \multicolumn{4}{|c|}{ Japan } & \multicolumn{4}{|c|}{ Korea } \\
\hline & & $\mathrm{FI}$ & NFC & GG & $\mathrm{HH}$ & $\mathrm{FI}$ & NFC & GG & $\mathrm{HH}$ \\
\hline \multirow[t]{4}{*}{ Japan } & $\mathrm{FI}$ & & & & & 11 & 20 & 3 & 0 \\
\hline & NFC & & & & & 5 & 9 & 1 & 0 \\
\hline & GG & & & & & 0 & 0 & 0 & 0 \\
\hline & $\mathrm{HH}$ & & & & & 0 & 0 & 0 & 0 \\
\hline \multirow[t]{4}{*}{ Korea } & $\mathrm{Fl}$ & 3 & 2 & 1 & 0 & & & & \\
\hline & NFC & 13 & 9 & 5 & 0 & & & & \\
\hline & GG & 17 & 0 & 0 & 0 & & & & \\
\hline & $\mathrm{HH}$ & 0 & 0 & 0 & 0 & & & & \\
\hline
\end{tabular}

Source: created by authors using CPIS data

Table 16 Incorporation of CDIS data for Japan and IBS into the International FIO Framework (in units of 1 billion USD)

\begin{tabular}{|c|c|c|c|c|c|c|c|c|c|}
\hline & & \multicolumn{4}{|c|}{ Japan } & \multicolumn{4}{|c|}{ Korea } \\
\hline & & FI & NFC & GG & $\mathrm{HH}$ & $\mathrm{FI}$ & NFC & GG & $\mathrm{HH}$ \\
\hline \multirow[t]{4}{*}{ Japan } & $\mathrm{Fl}$ & & & & & 4 & & & \\
\hline & NFC & & & & & & 31 & & \\
\hline & GG & & & & & & & & \\
\hline & $\mathrm{HH}$ & & & & & & & & \\
\hline \multirow[t]{4}{*}{ Korea } & $\mathrm{Fl}$ & 3 & & & & & & & \\
\hline & NFC & & 3 & & & & & & \\
\hline & GG & & & & & & & & \\
\hline & $\mathrm{HH}$ & & & & & & & & \\
\hline
\end{tabular}




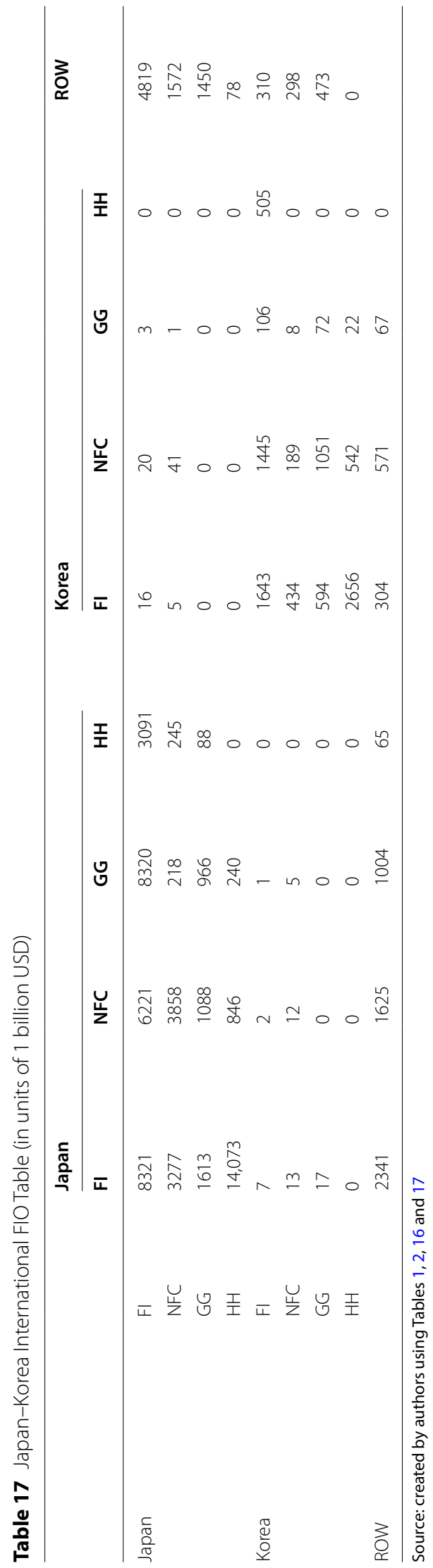




\section{combined in a matrix, a Japan-Korea international FFS table is estimated as shown in} Table 17.

\section{Abbreviations}

A: Assets; CB: Central Bank; CDIS: Coordinated Direct Investment Survey; CPIS: Coordinated Portfolio Investment Survey; FFA: Flow of Funds Account; FFS: From-whom-to-whom Financial Stock; FI: Financial Institution; FSB: Financial Stability Board; GG: General Government; HH: Household; IBS: International Banking Statistics; IIP: International Investment Positions; IMF: International Monetary Fund; IP: Insurance/Pension reserve; L: Liabilities; NFC: Nonfinancial Corporation; OECD: Organization for Economic Cooperation and Development; ODC: Other Depository Corporations; ROW: Rest of the World; SAFE: State Administration of Foreign Exchange; SDDS: Special Data Dissemination Standards; SEFER: Securities Held as Foreign Exchange Reserves; SNA: System of National Accounts; The U.S.: The United States.

\section{Acknowledgements}

Not applicable.

\section{Authors' contributions}

Hagino designed of the work and Kim made calculations. Hagino interpreted the results and made the first draft. Kim revised the manuscript and created figures. All authors read and approved the final manuscript.

\section{Funding}

Not applicable.

\section{Availability of data and materials}

Japanese benchmark input-output table is available on the website of the Ministry of Internal Affairs and Communication of Japan. Firm-level data of the Basic Survey of Japanese Business Structure and Activities are available through requests to the Ministry of Economy and Industry of Japan.

\section{Declarations}

Ethics approval and consent to participate

Not applicable.

\section{Consent for publication}

Not applicable.

\section{Competing interests}

The authors declare that they have no competing interests.

\section{Author details}

${ }^{1}$ Economic and Social Research Institute, Cabinet Office (ESRI), 1-6-1 Nagata-cho, Chiyoda-ku, Tokyo 100-8914, Japan. ${ }^{2}$ Graduate School of Humanities and Social Sciences, Okayama University, 3-1-1 Tsushima-naka, Kita-ku, Okayama 700-8530, Japan.

Received: 19 August 2021 Revised: 3 November 2021 Accepted: 8 November 2021

Published online: 18 November 2021

\section{References}

China Financial Yearbook Magazine (2016) Almanac of China's Finance and Banking 2016, China Finance Press Co. (in

\section{Chinese)}

Chinese Academy of Social Sciences (2017) Chinese Government Balance Sheet in 2017. (in Chinese)

Copeland MA (1952) A Study of Money flows in the United States, NBER

Errico L, Walton R, Hierro A, AbuShanab H, Amidzic G (2013) Global Flow of Funds: Mapping Bilateral Geographic Flows. In: Proceedings 59th ISI World Statistics Congress, pp 2825-2830. https://www.statistics.gov.hk/wsc/STS083-P1-S.pdf

Errico L, Harutyunyan A, Loukoianova E, Walton R, Korniyenko Y, Amidžić G, AbuShanab H, Shin HS (2014) Mapping the Shadow Banking System Through a Global Flow of Funds Analysis. IMF Working Paper, No.14/10

Hagino S, Kim J, Inomata S (2018) International Financial Input-Output Table for Asia-Pacific Region. IDE Discussion Paper, No.718

Hagino S, Kim J, Inomata S (2019) Development of U.S.-East Asia Financial Input-Output Table. IDE Discussion Paper, No.750

IMF and FSB (2009) The Financial Crisis and Information Gaps: Report to the G-20 Finance Ministers and Central Bank Governors

Ishida S (1993) Flow of Funds in Japanese Economy. Toyo Keizai Shinpo-Sha. (in Japanese)

Kim J (2013) The Comparative Analysis of Flow-of-Funds in Korea and Japan: using the Power of Liability and Asset Dispersion Indices. Innovation \& I-O Technique, 21(3):59-76 (in Japanese)

Lee H (2014) Compilation of Detailed Flow of Funds: Korea's Experiences. In: 7th IFC Conference on Indicators to support Monetary and Financial Stability Analysis: Data Sources and Statistical Methodologies, BIS in Basel https://www.bis. org/ifc/events/7ifcconf_lee.pdf 
LiY, Zhang X, Chang X (2015) Chinese National Balance sheet 2015'. Social Sciences Academic Press China, New York (in Chinese)

National Bureau of Statistics of China, 2017. China Statistical Yearbooks 2017, China Statistics Press. (in Chinese) http:// www.stats.gov.cn/tjsj/ndsj/2017/indexch.htm

Okuma R (2013) Sectoral Interlinkage in Balance Sheet Approach. IFC Bulletin, No. 36

Schumacher D (2019) The Integration of International Financial Markets: An Attempt to Quantify Contagion in an InputOutput-Type Analysis. Economic Systems Research, 31(3):345-360

Tang C (2018) Household Portfolio Choice in China: A Case Study of Shanxin. Quarterly journal of Institute of Developing Economies Japan External Trade Organization, 59(1):47-68 (in Japanese)

Tsujimura K, Tsujimura M (2008) International Flow-of-Funds Analysis: Techniques and Applications. Keio University Press, Keio (in Japanese)

Tsujimura K, Tsujimura M (2009) The Consequences of the Introduction of the Euro: A Nested Mixed-Effects Analysis of the International Banking Positions. Empirical Economics, 37(3):583-597

Tsujimura K, Tsujimura M (2010) A Flow-of-Funds Analysis of Quantitative Monetary Policy. In: Ichimura S, Klein LR (eds) Macroeconometrics Analysis of Japan. World Scientific, London, pp 193-193

Tsujimura K, Tsujimura M (2011) Balance Sheet Economics of the Subprime Mortgage Crisis. Economic Systems Research, 23(1):1-25

Yoshino N, Taghizadeh-Hesary F (2016) Causes and Remedies of the Japan's Long-lasting Recession: Lessons for China. China \& World Economy, 24(2):23-47

Zhang N (2009) Re-examination of the Theoretical Model for Global-Flow-of-Funds Analysis. Journal of Economic Sciences, 12:21-35

Zhang N (2005) The Composition of the Global Flow of Funds in East Asia. In: Tokimasa T, Yoshiaki Y (eds) Quantitative Economic Analysis, International Trade and Finance. Kyushu University Press, Kyushu, pp 175-187

Zhang N (2015) Measuring Global Flow of Funds and Integrating Real and Financial Accounts: Concepts, Data Sources and Approaches. In: Proceeding, 2015 IARIW-OECD Conference:W(h)ither the SNA? http://old.iariw.org/papers/ 2015/zhang.pdf

Zhang N, Zhao X (2019) Measuring Global Flow of Funds: Focus on China, Japan, and the United States. Economic Systems Research, 31(4):520-550

\section{Publisher's Note}

Springer Nature remains neutral with regard to jurisdictional claims in published maps and institutional affiliations.

\section{Submit your manuscript to a SpringerOpen ${ }^{\circ}$ journal and benefit from:}

- Convenient online submission

- Rigorous peer review

- Open access: articles freely available online

- High visibility within the field

- Retaining the copyright to your article

Submit your next manuscript at $\boldsymbol{\nabla}$ springeropen.com 